Religion and Gender, vol. 1, no. 1 (2011), 44-65

www.religionandgender.org

URN: NBN:NL:UI:10-1-101577

ISSN: $1878-5417$

Publisher: Igitur Publishing (Utrecht)

Copyright: this work is licensed under a Creative

Commons Attribution License (3.0)

\title{
Vital New Matters: The Speculative Turn in the Study of Religion and Gender
}

\author{
PAUL REID-BOWEN
}

\begin{abstract}
This article provides an introduction to a new trend in continental philosophy, the turn toward metaphysics, realism and speculative philosophy. This stands in sharp contrast with the antirealist and correlationist traditions that have held sway since Kant's Copernican Revolution in 1781. It is claimed that the study of religion and gender has been shaped by the antirealist legacy of Kant, but there are good reasons for taking account of the new 'speculative turn'. Two examples from the leading exponent of this turn, speculative realism, are introduced, and some provisional notes toward applying these to the gender-critical turn in the study of religion are considered. Research notes on the current state of the Goddess movement serve as a test case for the introduction of an object-oriented ontology into religious and gender studies.
\end{abstract}

\section{Keywords}

Antirealism, metaphysics, speculative realism, object-oriented, Goddess movement

\section{Author affiliation}

Paul Reid-Bowen is a senior lecturer in Philosophy and Ethics and Study of Religions at Bath Spa University, UK. His research and teaching interests 
encompass metaphysics, existentialism, ecological philosophy, new religious movements and religion and gender. He is currently working on two book projects, one on ecocide and human evolution, the other on applied objectoriented ontology. Email: P.Reid-Bowen@bathspa.ac.uk

\section{The speculative turn}

This article serves as a warning. Put briefly, I propose that recent tremors in the landscape of continental philosophy warrant close attention by students of religion and gender. Whether these disturbances point towards a forthcoming geo-theoretical upheaval, the shockwaves of which might be felt throughout the humanities, social sciences and far beyond, or else are a localized phenomenon, the product of released tensions along wellunderstood fronts of academic disagreement, is, as yet, undecided. Predicting future trends in academic theorizing is as contentious and likely to fail as forecasting the weather, playing the stock market or pinning down the Big One. However, the tremors are real. They are the product of a demographically and geographically diverse group of philosophers, ranging from full professors to research students and independent scholars, who, through cross disciplinary alliances and some fertile examples of intellectual outreach, are attempting to rejuvenate speculative philosophy. ${ }^{1}$ In sum, it is arguable that there is a new philosophical movement on the scene; it is gathering force; and it is making a difference beyond its immediate environs. My somewhat partisan aim is to introduce some elements of this movement and propose that it has the potential to change the study of religion and gender for the better. I will share some research notes on the Goddess movement to demonstrate some implications of the speculative turn for the study of religion and gender.

The current rumblings in continental philosophy can be characterized in a number of ways. In simple terms they denote two proposals: the first, a

1 Two clarifications: first, it is notable that the gender distribution of this group is highly skewed toward men. This is a matter of considerable concern but at present only Isabelle Stengers is directly identified with the group. The work of scholars such as Karen Barad, Jane Bennett, Rosi Braidotti, Elizabeth Grosz and Donna Haraway could, though, easily be included. See M. O'Rourke, 'Girls Welcome!!!' Speculative Realism, Object Oriented Ontology and Queer Theory' in Speculations II (2011), 275-312. Second, the group has a considerable Web 2.0 presence, with all of its members making extensive use of the blogosphere as a medium for philosophical discourse and interchange. A useful gateway site is Speculative Heresy,

http://speculativeheresy.wordpress.com/. 
return to speculative metaphysics, the second, an embrace of realism. There is, however, little that is particularly easy or straightforward about the implementation of either of these things. A major overhaul in the commitments of continental philosophy would seem necessary in order for them to acquire any purchase or momentum. The recent history of continental philosophy has tended to dismiss all talk of realism as part of a naive 'pseudo-problem'. The choice between realism and antirealism, or realism and idealism, has been critiqued and caricatured as far too brutal a bifurcation of the world to be taken seriously. Moreover, when one does examine recent continental philosophy more closely, one is confronted with arguments that are, at their core, antirealist in nature. ${ }^{2}$ So, on the one hand, continental philosophy displays an unwillingness to make the choice between realism and antirealism, while, on the other, it encompasses arguments and traditions that are antirealist. Clearly, for anyone with metaphysical and realist commitments this is difficult and frustrating terrain to traverse. The intellectual legacy here is that of Immanuel Kant and his Copernican Revolution, instituted with the publication of the Critique of Pure Reason in 1781. It was Kant who placed severe limits on metaphysical speculation, elaborating and systematizing how a priori categories of human cognition and understanding impose order on the world. Following Kant, knowledge of the things-in-themselves is rendered illegitimate. The concerns of philosophy shift toward interrogating the gap between human and world, problems of access and critique. Always and everywhere the world is structured by human cognition, rather than vice versa. Any differences between analytical and continental philosophers are remarkably minor in this regard. Both take Kant's arguments seriously, implicitly affirming Slavoj Žižek's identification of Kant as the first philosopher; $^{3}$ and many concur with Frederick Ferre's observation that metaphysics has become a 'miserable word.' ${ }^{4}$ Only very recently has this state of affairs been called into question.

The revival of metaphysics and realism in continental philosophy might be traced to the work of Gilles Deleuze, Bruno Latour's ActorNetwork-Theory, or, more plausibly, the Anglo-American influence of $A$. $N$. Whitehead's process metaphysics. However, it was not until 2002 that the

2 L. Braver, A Thing of This World: A History of Continental Anti-Realism, Evanston, IL: Northwestern University Press 2007.

3 S. Žižek, Organs Without Bodies: On Deleuze and Consequences, New York: Routledge 2004.

4 F. Ferré, Being and Value: Toward a Constructive Postmodern Metaphysics, New York: SUNY Press 1996, 1. 
continental philosophers Manuel DeLanda and Graham Harman were on record as advocating metaphysics and realism, and it was only in 2007 that a more unified showing of such commitments became discernible. A small conference at Goldsmiths's College, London, in April 2007, featuring Quentin Meillassoux, Ray Brassier, lain Hamilton Grant and Graham Harman, was the venue at which continental realism cohered and where a title under which it might subsequently operate was agreed: speculative realism. ${ }^{5}$ These philosophers were not joined in their methods, philosophical sources or even attitudes to the title of speculative realism, but they did agree on their main adversary: correlationism.

In 2006 Meillassoux had published After Finitude, ${ }^{6}$ an intense and uncompromising work in which he defined and critiqued contradictions in the post-Kantian philosophical tradition and then proceeded to engineer an escape from them. Meillassoux's target encompassed transcendentalism, phenomenology, post-phenomenology and the many contemporary critical theories that rested on them. His ability to draw these together was founded on what he termed their shared commitment to correlationism, the proposal 'that there are no objects, no events, no laws, no beings which are not always-already correlated with a point of view, with a subjective access. ${ }^{7}$ The crux of this claim is that thinking and being are only accessible in their co-relation, never in their own right. Kant's transcendental argument is exemplary of this, but it informs, with several variations, the whole of contemporary continental philosophy. It is also notable that, for Meillassoux, correlationism is synonymous with antirealism. What follows from this? Following Kant, epistemology was enthroned as first philosophy, and its primary concern became, where to begin in thought. It is this focus which the speculative realists oppose.

One might question the motives of these continental and speculative realists; they certainly differ. I offer three possibilities that may promote some understanding. First, it does not seem too controversial to suggest that the global ecological and economic crises, the ever-increasing

5 Representative works include Q. Meillassoux, After Finitude: An Essay on the Necessity of Contingency, London: Continuum 2009; I. H. Grant, Philosophies of Nature After Schelling, London: Continuum 2008; R. Brassier, Nihil Unbound: Enlightenment and Extinction, New York: Palgrave Macmillan 2010; G. Harman, Tool-Being: Heidegger and the Metaphysics of Objects, Chicago: Open Court 2002.

6 Or rather the French edition, Après la Finitude, was published in 2006; the English edition did not first appear until 2008.

7 This is derived from an introductory paper to his work, given by Meillassoux, and cited in P. J. Ennis, Continental Realism, Winchester: Zer0 Books 2011, 4. 
incursions of technology into the human life world, or the escalating awareness of existential dangers, such as meteors, pandemics, resource depletion and supervolcanoes, have placed the ascendency of the human subject in question. This has led some to claim that the dominant antirealist strain of continental philosophy has not only reached a point of decreasing returns, but that it now actively limits the capacities of philosophy in our time. ${ }^{8}$ The focus on the human-world correlate consciousness, discourse, language, power, text and so on - now seems signally inappropriate for wrestling with the problems at hand. There is a pressing demand for 'turning once more toward reality itself. ${ }^{9}$ Similarly, one may be of the view that the many children of Kant's Copernican Revolution have now reached an impasse. That is, everywhere one looks, there is a 'conflict of critiques'. Whether Kantians, Marxists, Husserlians, Heideggerians, Foucauldians, Derrideans, Lacanians, Gadamerians or Wittgensteinians, all propose their favoured critiques and points of epistemological access. But there is no means to choose between them. ${ }^{10}$ Finally, as many speculative realists propose, correlationism itself may be overcome. The Copernican Revolution need never have been accepted in the first place. How, then, to proceed?

Speculative realism is taken as the point of entry into continental realism. By way of definition, the movement is realist in its opposition to correlationism and speculative in that the models of reality it produces might be contrary to common sense, counter-intuitive, or even weird. ${ }^{11}$ As a supplement to this, one might also think of the speculative realist as asking, "[w] hat if we were to "bracket" the project of critique and questions of access, and proceed in our speculations as the beginning student of philosophy might begin?'12 The speculative wager here is that, 'such a naive and pre-critical beginning might give us the resources to pose differently the philosophical questions we have inherited, thereby opening up new possibilities of thought and a line of flight from a framework that has largely exhausted itself and become rote. ${ }^{13}$ What, though, might the

8 L. Bryant, N. Srnicek and G. Harman (eds.), The Speculative Turn: Continental Materialism and Realism, Melbourne: re.press 2011, 3.

9 Ibid.

10 L. Bryant, 'The Ontic Principle: Outline of an Object-Oriented Ontology' in L. Bryant, N. Srnicek and G. Harman, The Speculative Turn, 262.

11 See Bryant, Srnicek and Harman (eds.), The Speculative Turn and Ennis, Continental Realism.

12 L. Bryant, 'The Ontic Principle', 263.

13 L. Bryant, 'The Ontic Principle', 263. 
relevance of this be for the study of religion and gender? There has often been a valuable interchange between continental philosophy, religious studies and gender studies. But metaphysical speculation may sit rather less well with disciplines and subjects that have favoured epistemological questions and their own projects of critique.

\section{The Gender-Critical Turn}

The core insights of the gender-critical turn in religious studies warrant little historical and systematic elaboration here. It was only during the relatively recent past, notably the late 1970s, that numbers of academics began to deploy gender theoretical perspectives within the field of religious studies. This was initially driven by a feminist identification and critique of the gender bias and blindness operative within both religious studies and the traditions that were its subject. This, though, was soon overtaken by a more wide-ranging application of gender analysis, an application that some confidently claimed to signal a paradigm shift in the study of religions. Ursula King, for example, writing in 1995, outlined four dimensions of the imminent disciplinary upheaval. First a descriptive dimension, arising from the discovery and generation of new data, experiences, materials and questions provided by gender analysis. Second, a negative-critical dimension, emerging from the deconstruction and hermeneutical interrogation of religious and scholarly texts and traditions through a gender-sensitive lens. Third, a positive-critical dimension entailing the reconstruction of religions along gender informed and sensitized lines. And fourth, a methodological dimension, building on the aforementioned identification of gender bias and blindness, but quickly moving to transform research programmes and methods through the integration and application of gender theory. ${ }^{14}$ It remains to be answered to what extent this global shift and transformation of religious studies has occurred.

What is beyond doubt is that the theorization of religion and gender proved to be a dynamic and fertile area of academic activity, stimulating heated philosophical and religious debates, promoting original inter- and transdisciplinary dialogues and projects, and pushing methodological reflexivity to ever higher levels of intensity. In its short history, the study of religion and gender has not stood still, or avoided the expansion of its concerns, or resisted the need to substantially revise its

${ }^{14}$ U. King (ed.), Religion and Gender, Oxford: Blackwell 1995, 27-28. 
guiding principles. Early conceptualizations of sex as biological/natural and gender as culturally and socially constructed, for example, gave way to the theorisation and general acceptance of sex as a construct too. But alongside this important change, one must also include and integrate: the implications and theorizations of class, ethnicity and race; analyses of the history and legacy of colonialism and imperialism; systematic feministdriven philosophical, psychological and psychoanalytic reflections on the nature of subjectivity, power and language; the conceptual decoupling of sexuality from both gender and sex; the emergence of gay, lesbian and transsexual studies and queer theory; and an outpouring of inter- and intra-religious dialogue, ethics and theology aimed at religious, social and political reform. While there may be some debate about the numbers of scholars working in this field, there is little doubting the seriousness and sophistication of the work that has been undertaken.

The adaptability and reflexivity of the study of religion and gender has been impressive, but one wonders whether it is vulnerable to the criticisms of the speculative turn? Are there grounds for continued optimism? Has a point of diminishing returns been reached? Is there a need to turn to reality itself? My aim here is not to insult fellow academics with the claim they are not in touch with reality. I only bring to light the hesitancy, or a wilful resistance, toward metaphysical questions that afflicts this discipline, as it troubles the humanities more generally. An awareness of this failure seems evident in ever increasing attempts to adequately theorize and integrate corporeality, embodiment and the flesh within religious and gender studies. Awkwardly, such attempts frequently lapse, or collapse, into the language of social construction, inscriptive regimes and the body as text. Few are willing to risk the embarrassment of metaphysics, the taint of essentialism, or the accusation of being precritical. Some transitions can be noted in the growth of materialist feminisms, new materialisms and the posthumanities. ${ }^{15}$ But I suspect only continental realism and the speculative turn may force the issue. Let us

15 S. Alaimo and S. Hekam (eds.), Material Feminisms, Bloomington, IN: Indiana University Press2008; K. Barad, Meeting the Universe Halfway: Quantum Physics and the Entanglement of Matter and Meaning, Durham: Duke University Press 2007; D. H. Coole and S. Frost (eds.) New Materialisms: Ontology, Agency, and Politics, Durham, NC: Duke University Press 2010; D. Haraway, 'Manifesto for Cyborgs: Science, Technology, and Socialist Feminism in the 1980s' in Socialist Review 80 (1985), 65-108; E. Grosz, Volatile Bodies: Toward a Corporeal Feminism, Hoboken, NJ: John Wiley \& Sons 1994. 
consider two possibilities: vibrant materialism and object-oriented ontology.

\section{A Political Ecology of Things}

Jane Bennett's Vibrant Matter is a valuable point of introduction to the speculative turn and a gateway into disciplines cognate with religious and gender studies. ${ }^{16}$ Although not a member of the initial coterie of speculative realists, her work has been widely read, positively reviewed, and actively appropriated by those who self-identify with the movement. Peter Gratton notes from his teaching of speculative realism that Bennett usefully brings together and articulates many of its main themes. ${ }^{17}$ Graham Harman, in turn, considers it particularly encouraging that 'as candid a work of metaphysics' could emerge from within a Political Science department, adding that '[p]erhaps philosophical speculation on fundamental topics is poised to make a comeback throughout the humanities. $^{18}$

To begin, Vibrant Matter marks a return to thinking the things themselves. Bennett argues for nothing less than a reconceptualization of matter, a re-imagining of the human relationship with the nonhuman, and finally what she terms a political ecology of things. Her project entails making breaks with previous approaches to materialism and an assault on some of the major bifurcations to have dominated the conceptual frameworks of the west: subject-object, organic-inorganic, active-passive and, by implication, human-world. The primary claim is that non-human matter can possess a kind of agency and the line drawn between active humans and inanimate matter is far more controversial and malleable than most believe. Drawing a close alliance with the work of Bruno Latour, she deploys the concept of actants. These, she explains, 'can be human or not, or most likely a combination of both.' The world is replete with these actors and agencies. More expansively,

an actant is neither an object nor a subject but an 'intervener' akin to the Deleuzean 'quasi-causal operator'. An operator is that which, by virtue of its

16 J. Bennett, Vibrant Matter: A Political Ecology of Things, Durham: Duke University Press 2010.

17 Peter Gratton, Philosophy in a Time of Error, 'Vibrant Matters: An Interview with Jane Bennett,'

http://philosophyinatimeoferror.wordpress.com/2010/04/22/vibrant-matters-aninterview-with-jane-bennett/; accessed 12 September 2011. 
particular location in an assemblage and the fortuity of being in the right place at the right time, makes the difference, makes things happen, becomes the decisive force catalyzing an event. ${ }^{19}$

Her aim here is nothing short of a reformulated vitalism, in which it becomes increasingly necessary to think in terms of multiple modes and degrees of agency. She de-emphasizes the human, directing attention towards networks of change, more-than-human assemblages, and the agentic contributions of myriad nonhumans to socio-political events. One of her main operating terms is 'thing-power', which she elaborates through carefully developed examples and case studies. This thing-power requires its own vocabulary, shifting attention away from the singular authorial power of human decision-making and intentionality toward distributed fields of force. Terms such as productive power, propensity, trajectory and vital impetus become far more appropriate for the interplay of matter she outlines. Her concerns are clearly speculative, but also systematic, realist and linked back to the humanities at various points. As she asks, drawing on the parlance of Latour:

What would happen to our thinking about nature if we experienced materialities as actants, and how would the direction of public policy shift if we attended more carefully to their trajectories and powers? I am looking for a materialism in which matter is figured as a vitality both inside and outside ourselves, and is a force to be reckoned with without being purposive in any strong sense. ${ }^{20}$

One can barely start to imagine how this revised landscape might play out if and when applied to religious and gender systems. Bennett champions the ability of everyday objects to exhibit a degree of independence, a capacity to exceed the conceptual frames that we impose on them, becoming 'vibrant things with a certain affectivity of their own'. ${ }^{21} \mathrm{Her}$ theorization of material agency draws on and adapts the Deleuzean concept of assemblages. No longer is agency firmly anchored within the human, but it is the product of often dispersed but internally related, human-nonhuman aggregates. One example that she unravels is that of the electrical power grid and the case of a widespread blackout in North America in 2003. The blackout, she notes, was extruded 'from multiple sites or many loci ... a quirky electron flow and a spontaneous fire to members of Congress who have a neoliberal faith in market self-

\footnotetext{
19 J. Bennett, Vibrant Matter, 9.

20 Ibid., 62.

21 Ibid., xvi.
} 
regulation.' There was, 'not so much a doer (an agent) behind the deed (the blackout) as a doing and an effecting by a human-nonhuman assemblage. ${ }^{22}$ Ethical problems and questions follow from such revised metaphysical framings of agency, a fact Bennett clearly recognizes. However, she argues that human intentionality, interiority and reflexivity have always been shaped by human tool-use and encounters with the nonhuman. The case for religious and gender identities being shaped by interactions with complex networks of materialities does not seem too contentious in this regard.

\section{A Democracy of Objects}

A speculative metaphysic sharing some affinities with Bennett's vibrant materialism, is that of object-oriented ontology. It is worthwhile dedicating rather more space to this, given that it is perhaps the largest and most developed wing of speculative realism, featuring the work of four active contributors: Graham Harman, Levi Bryant, lan Bogost and Tim Morton Moreover, it has shown itself to be the most amenable and committed to applications beyond its immediate environment. ${ }^{23}$ Taking Vibrant Matter as a point of departure, for Bennett metaphysical emphasis typically rests with the agentic potential of more-than-human assemblages, in which material objects may blur or dissolve into one another, and where there is a presumption of 'one matter-energy' subtending these formations. ${ }^{24}$ By contrast, for object-oriented ontologists it is individual objects that are the primary units of reality, and, although not adverse to assemblages, they staunchly oppose the dissolution of individual things and the positing of any underlying metaphysical substrates or unities. For want of a better phrase, it is objects all the way down.

In order to elaborate basic object-oriented principles, certain differences between the main writers may be elided. I will limit myself to four fundamental principles here. First, objects are the basic units of reality,

\footnotetext{
Ibid., 28.

See L. Bryant, 'The Ontic Principle; L. Bryant, Larval Subjects, http://larvalsubjects.wordpress.com (access date 12 September 2011); L. Bryant, The Democracy of Objects, Open Humanities Press 2011; G. Harman, Prince of Networks: Bruno Latour and Metaphysics, Melbourne: re.press 2009; G. Harman, Guerrilla Metaphysics: Phenomenology and the Carpentry of Things, Chicago: Open Court 2005; G. Harman, The Quadruple Object, Winchester: Zer0 Books, 2011; G. Harman, ObjectOriented Philosophy, http://doctorzamalek2.wordpress.com (access date 12 September 2011).

24 Bennett, Vibrant Matter, 122.
} 
and subsequently the primary concern of philosophy. Whether atoms, angels, chairs, choirs, elephants, epistles, galaxies or gods, all of these are to be understood as objects. This is not to suggest, to cite Harman, that 'all objects are equally real, but that they are equally objects. It is only in a wider theory that accounts of the real and unreal alike that pixies, nymphs, and utopias must be treated in the same terms as sailboats and atoms. ${ }^{25}$ The task of the object-oriented philosopher is to deliver this wider theory. Second, objects exist at all scales and sizes, and no scale or size is to be privileged. To oppose either of these first two principles is to be committed to the undermining and/or overmining of objects. The history of philosophy is replete with such attempts. Undermining may move from pre-Socratic postulates of an apeiron, or primary element, through to contemporary scientific and physicalist reductionism, with the positing of particles as the basic blocks of reality, or even recent continental metaphysical concepts, such as Deleuze's 'virtual plane'. Overmining, in turn, is best represented by the correlationist ensnarement of objects in the human-world correlate, although it may also be explained as any position that sets up the experience or manifestation of the object in the mind as that which is of primary significance. Empiricists, for example, may overmine objects as bundles of qualities that are brought under concepts in the mind. ${ }^{26}$

Third, the human-world relation loses all priority. That is, ontologically, there is nothing particularly special or interesting about the human-world gap. To cite Harman, 'the interaction between cotton and fire belongs on the same footing as human interaction with both cotton and fire. ${ }^{27}$ Human encounters with other objects are no more special than those of bacteria or household furniture with those objects. Fourth, objects are external to their relations. This is perhaps one of the stranger premises of object-oriented ontology. Many people's intuitions and many theories suggest that the objects of the world are constituted through their relations with other objects. The object-oriented response to this is that it leads toward a veritable 'hall of mirrors', in which the being of objects is infinitely deferred. Ultimately, everything dissipates and vanishes beneath any such totalizing relationism. ${ }^{28}$ This is not to say that objects do not enter into relations with other objects. They frequently do. But real objects

\footnotetext{
G. Harman, The Quadruple Object, Winchester: Zer0 Books2011, 5.

Ibid., 8-13.

Ibid., 6

28 Harman, Guerrilla Metaphysics, 82.
} 
always exceed their external relations. No specific relations can either capture or exhaust any real object. Indeed, in order to clarify this, Harman draws a distinction between the real object and the sensual object. The real object is what might be referred to as the object-for-itself. The real object is never accessible, either to us or any other object directly. Interactions only take place with sensual objects, and these interactions occur via the specific external relations into which a real object might enter. By way of example, consider multiple interactions with a road-side shrine - a real object. The passage and ritual contact of human travellers will inevitably touch on certain sensual qualities of the shrine; the contact of passing pigeons, foxes and insects will engage with others, just as the contact of rain, snow, wind and photons will interact with yet others. But all of the contacts are with the sensual object. The real shrine is withdrawn behind all of the interactions. It is never fully deployed in any of them. There is the shrine for the devout pilgrim, the shrine for the questing ant, the shrine for first snowflake of winter, but the real shrine recedes behind these sensual encounters. No total description can capture the real shrine.

All of these points can benefit from further elaboration and warrant defence against rejoinders. Harman, for example, has four poles in his account of the nature of objects, encompassing the aforementioned real and sensual objects, in addition to real and sensual qualities, and ten linkages or tensions between them. Systematically he has worked outwards from this quadruple structure of objects toward intriguing and provocative accounts of causation, space and time. The debates about these objects, though, are ongoing, encompassing such topics as the precise nature of change and relationality and the ethical and political upshot of the metaphysic. Levi Bryant's Democracy of Objects explores some alternative approaches to the principles introduced above. For example, Bryant champions different allies than those favoured by Harman, such as Roy Bhaskar, Gilles Deleuze and Niklas Luhmann, and dedicates more space toward theorizing complex and negentropic systems as objects. However, the anti-correlationist, object-oriented and realist commitments remain the same. The Kantian imposed cycle of critique, with its antirealist closure of metaphysical speculation, is viewed as neither necessary nor a source of philosophical virtue. The object-oriented ontologists might applaud some insights generated by the Copernican Turn, particularly with regard to social phenomena, such as the gendercritical turn, but they argue that new models of reality are required, 
especially ones that can retain these positive insights, while escaping the obsessive focus on the human-world gap. ${ }^{29}$

\section{An Object-Oriented Study of Religion and Gender}

Converting readers to particular metaphysical frameworks is not the intent of this article. The extensive arguments of Bennett, Harman, Bryant and others need to be individually examined and weighed in this regard. What is crucial, is that an ethos or promise of doing justice to reality is taken seriously. The proposal is simply that new possibilities of thought may be opened up by shifting emphasis from epistemology to metaphysics. Speculative metaphysics may seem a kind of wager, but its rapprochement with reality may pay considerable returns, particularly when compared with the diminishing returns of anthropocentric critiques.

What might any of this mean for the study of religion and gender? What might be the methodological affordances, problems or dilemmas? A provisional sketch of some directions and research programs is offered in what follows. Rather than attempting to incorporate continental and speculative realism as a whole, its focus is directed toward object-oriented ontology. This choice is based on my familiarity with it and the knowledge that some applications of this approach have already started to appear across the arts and humanities. The $24^{\text {th }}$ Annual Conference of the Society for Literature, Science and the Arts in 2010, for example, featured two panels under the heading of object-oriented feminism, including papers on topics such as Botox and plastic surgery, software design, transgenic technologies, and the corset. There would seem to be capacity for the implementation of similar approaches at the interface of religious studies and gender studies too.

The practical first step toward applying object oriented approaches to the humanities, arts and social sciences is decentring the human. Thus, while the primary subject of analysis in the study of religion and gender may have been gender bias, object oriented ontology requires the displacement of human bias. This may include: the removal of the human as primary focus of attention; the human as the only or primary source of agency; and the human as the only or primary source of value. What then follows from this decentring? Arguably, the primary outcome is enhanced sensitivity to the affects and powers of objects, specifically to construct,

See L. Bryant, Onticology - A Manifesto for Object-Oriented Ontology Part I; http://larvalsubjects.wordpress.com/2010/01/12/object-oriented-ontology-amanifesto-part-i/ (access date 12 September 2011). 
obstruct and perturb other things of the world. All talk of social constructivism, along with undue attention to the power of discourse, language and text, needs to be set aside and replaced by a far more inclusive constructivism, one that recognizes the contribution of many diverse objects and materials to the constitution of the world.

What objections might arise to these initial points? Two initial ones might be stated in terms of accusations of antihumanism and objectification. That is, the decentring of humans may be identified with a denigration of the human, and the characterization of humans as objects may be viewed as an invidious reduction of humans to the status of objects. Both of these points can be rather quickly dismissed. First, there is nothing in the removal of humans from the centre of analytical, interpretive and methodological frameworks that also attributes a negative value to those humans or else vacates value from the human. Second, accusations of the objectification of humans simply miss the theoretical content of the ontology that is proposed. As Harman elaborates on the matter,

the objects of object-oriented philosophy have nothing to do with objectification. In fact, they are what resist all objectification. To objectify someone or something is to limit it, to reduce it: 'You are nothing but slave labor - gather my crop, under penalty of death!', 'You, supposed mind, are nothing but a physical brain!' ... By contrast, object-oriented philosophy is by definition an anti-reductionist philosophy. It holds that all things must be taken on their own terms. The reason for complaints about 'objectification' is that a false split is made between people and maybe animals who cannot be objectified, and inanimate objects which can. My thesis, by contrast, is that even inanimate objects should not and cannot be objectified. It's not about 'reducing people to objects' but about raising the status of objects to the level of people. ${ }^{30}$

What, then, of the status of religion and gender in these analyses? Can the specificity of either analytical term be retained when allied and combined with an object-oriented approach? A response to the religious element is perhaps the easiest of the two to formulate. The historical landscape of religious studies has numerous examples of methodological approaches which either encourage the foregrounding of objects in their analyses, or else treat religions as complex objects in their own right. Ninian Smart's

30 Harman, Object-Oriented Philosophy, http://doctorzamalek2.wordpress.com/2010/01/22/levi-on-reid-bowen-on-feminismand-ooo/ (access date 12 September 2011). 
construal of religions as multidimensional organisms, for example, encompasses both of these possibilities, by listing the material, textual, experiential and performative dimensions that need to be considered in order to grasp a religion in its unity. ${ }^{31}$ Smart's model of religion has suffered extensive criticism since its inception, perhaps especially because of its phenomenological underpinnings, but it is remarkably amenable to an object-oriented approach, especially one that is prepared to view religions as a complex assemblages, comprised of countless other objects.

The question of whether one can usefully retain gender in an object-oriented analysis is perhaps more contentious. The fact that gender studies start with a human subject implies an already given enthrallment to the correlationism that the speculative turn aspires to bypass. An approach that is opposed to anthropocentrism might be expected to exhibit a disinterest in, or else a distancing from, analyses of gender. What precisely could an object-oriented approach to gender look like? The points that follow indicate a way forwards, but they are proposals and hypotheses at best. First, there is no denial within object-oriented ontology that objects are acted upon and affect one another; objects do relate to one another, but they are not defined by, or reducible to, their relations. Second, it remains the case that humans as objects are differentially acted upon in accordance with such factors as the kind of objects that they are - for example, female, male, old, young, diseased, healthy - and also the kind of object that they are identified as being. Third, humans are also members of larger objects, such as organizations, religions and societies, just as they are, in part, comprised of smaller objects, such as bacteria and microbes. None of these points denies the existence of gender or rides rough-shod over any specific tools of gender analysis. What an object-oriented ontology does is multiply the number of actants and objects that participate in the construction of gendered individuals. Social constructivism may have accommodated such considerations as age, class, ethnicity, race and sexuality within its analyses, object-oriented ontology ratchets up the complexity and intensity of the constructivism by bringing many additional objects to the table for inclusion.

The only significant object-oriented discomfort that may afflict students of religion and gender is likely to arise from the point that causal authority no longer rests with the human. The sovereignty of human intent

31 N. Smart, Dimensions of the Sacred: An Anatomy of the World's Beliefs, Waukegan, IL: Fontana Press, 1997; N. Smart, The World's Religions, Cambridge: Cambridge University Press 1998. 
is overturned by object-oriented ontology. All objects may affect, construct and translate one another; or, if one favours Bennett's work, one would need to take account of different degrees of agency. If implementing an object-oriented study of Roman Catholicism, for example, it might be just as reasonable to be concerned with the affects and causal powers of cassocks, cathedrals and church mice, as with those of clerics, choirs and creeds. Fortunately, studies in this genre are not wholly without precedent within religious studies and the humanities. From Elisabeth Eisenstein's systematic two volume analysis of the revolutionary agentic role of the printing press in the Reformation, through to Marcella Althaus-Reid's evocative and queer opening meditation on lemons, odours and underwear in Indecent Theology, it is clear that there are starting points for object-oriented forays into religion and gender. ${ }^{32}$ One might want a more prescriptive agenda, a refined set of procedures, or else clearly defined set of outcomes in place before beginning such studies. However, as Michael O'Rourke has argued, drawing on Agamben's concept of 'the open,' '[t]here can be no program for what ... speculative realism or object oriented approaches do. They are not means to an end, but rather means "without end." 33 This assertion speaks to the complex, queer and weird entites with which one may inevitably need to grapple with these approaches. Similar to the bridgehead problem in anthropology, one may need to deploy a hermeneutical to-and-fro search in order to start to make sense of one's environment. Except, in this sense, one is engaged in a 'hermeneutics of the real', rather than one of cultural signs, signifiers and symbols alone. In the following section I share some research notes on my efforts to import an object-oriented approach into the field of religious studies with which I am most familiar: the Goddess movement. This is not, I stress, a neatly packaged case study, it is rather a work in progress that has recently considered object-oriented perspectives in order to see what emerges.

\section{A Girl's Best Friend and Webs of Power}

The Goddess movement was one of several religious movements that coalesced during the 1970s and 1980s. Taking impetus from the women's movement and new social movements for peace, ecology and alternative

32 E. Eisenstein, The Printing Press as an Agent of Change, Cambridge: Cambridge University Press 1980 and M. Althaus-Reid, Indecent Theology: Theological Perversions in Sex, Gender and Politics, London and New York: Routledge 2000, 1-4. 
lifestyles, the Goddess movement interwove these concerns with a more encompassing project of spiritual discovery, empowerment and revolt. Its membership was predominantly, although not exclusively, female. They were primarily located in North America, Europe and Australasia, and they shared many demographic features with the New Age, the Pagan Revival and a range of reformist feminist theologies. Significantly, though, their overriding concerns were separable from these other movements. They expressed a desire to explore the meaning of female deity, to reclaim and ritualize female sacrality and spirituality, to re-mythologize the world according to a female and/or feminist imaginary, to empower and liberate women, and to challenge the hegemony of patriarchal social and religious power. Other spiritual matters were secondary. Self-identified insiders such as Asphodel Long, Carol Christ and Starhawk have produced influential works expressing the movement's beliefs, practices and thealogies, ${ }^{34}$ while academics such as Naomi Goldenberg, Melissa Raphael and Cynthia Eller have delineated and theorized the movement in historical, phenomenological and social scientific terms. ${ }^{35}$ It is not my purpose to substantially reproduce those results here, only certain salient features.

In its formative years, notably the 1970s and 1980s, the Goddess movement exhibited a range of attitudes towards female deity. As Carol Christ summarized in a threefold typology, members of the movement might hold to any of the following views:

(1) the Goddess is divine female, a personification who can be invoked in prayer and ritual;

34 A. Long, 'The Goddess Movement in Britain Today' in Feminist Theology 5 (1994), 11 39; A. Long in 'The One and the Many: The Great Goddess Revisited' in Feminist Theology 15 (1997), 13-29; C. Christ, 'Why Women Need the Goddess: Phenomenological, Psychological, and Political Reflections' in C. Christ and J. Plaskow, (eds.), Womanspirit Rising: A Feminist Reader in Religion, San Francisco: HarperSanFrancisco 1992, 273-287; C. Christ, Rebirth of the Goddess: Finding Meaning in Feminist Spirituality, New York: Addison Wesley 1997; Starhawk, The Spiral Dance: A Rebirth of the Ancient Religion of the Great Goddess, San Francisco: HarperSanFrancisco 1999 [1979]; Starhawk, Dreaming the Dark: Magic, Sex and Politics, Boston MA.: Beacon Press 1997 [1982].

C. Eller, Catherine, Living in the Lap of the Goddess: The Feminist Spirituality Movement in America, New York: Crossroad 1993; N. Goldenberg, Changing of the Gods: Feminism and the End of Traditional Religion, Boston: Beacon Press 1979; M. Raphael, 'Truth in Flux: Goddess Feminism as a Late Modern Religion', Religion, 26 (1996), 199213. M. Raphael, Thealogy and Embodiment: The Post-Patriarchal Reconstruction of Female Sacrality, Sheffield: Sheffield Academic Press 1996; M. Raphael, Introducing Thealogy: Discourse on the Goddess, Cleveland, OH: The Pilgrim Press 2000. 
(2) the Goddess is symbol of the life, death and rebirth energy in nature and culture, in personal and communal life;

(3) the Goddess is symbol of the affirmation of the legitimacy and beauty of female power (made possible by the new becoming of women in the women's liberation movement). ${ }^{36}$

These perspectives could be elaborated and combined in various ways without disagreements or internal tensions surfacing. Thus, deity could be experienced, evoked and ritualized as single (the Great Goddess, the Mother Goddess), as triple (Maiden, Mother, Crone) and/or through culturally, religiously and mythically diverse individual goddesses (Athena, Cerridwen, Isis, Hecate, Kali, Tara and others). Female sacrality, in turn, could be either located within, as an energistic, psychic or archetypal reality, or projected outside, as a transcendent hypostatization of certain female qualities, as a combination of both, such as the life, death, rebirth energy cited above, or else as something else entirely. The movement demonstrated a 'democratic plurivocality', a remarkable tolerance of difference, with writers such as Long arguing that only the idea of female deity mattered because it affirms that women can have a close relationship with the divine ... however that divine is envisaged. ${ }^{38}$ This state of affairs did not persist.

From the late 1980s and early 1990s tensions could be identified within the Goddess movement. Despite an ongoing resistance to argumentative relations with their fellows, alternative interpretations of the nature of Goddess were becoming important. A non-comprehensive list of tensions includes: realist vs antirealist, singular/Goddess vs plural/goddesses, Pagan vs New Age, feminist vs nonfeminist, countercultural vs conservative, exoteric vs esoteric. Some evidence of these tensions in the United Kingdom could be discerned in the Challenging New Age Patriarchy conference, at Malvern in 1990, the appearance of The Journal of Radical Feminist Spirituality, Magic and the Goddess: From the Flames and Monica Sjöö's New Age \& Armageddon. ${ }^{39}$ All of these voiced a strong dissatisfaction with developing trends, frequently articulated in terms of depoliticization, New Age appropriation, commodification and hijacking. A contributor to the journal From the Flames is representative of these concerns:

\footnotetext{
Christ, 'Why Women Need the Goddess', 278.

Raphael, 'Truth in Flux', 200.

Long, 'The One and the Many', 22, 25.

39 M. Sjöö, New Age \& Armageddon: The Goddess or the Gurus? Towards a Feminist Vision of the Future. London: The Women's Press 1992.
} 
Slowly over the years, as I have seen a rise in goddess consciousness and a growth in the wimmin's spirituality movement, I have also seen a decline in radicalism. Somehow, and it happened gradually, the re-emerging goddess has been co-opted into the new 'growth movement'. She has been 'prettied up', tamed and made acceptable. Instead of being something elementally challenging, our spirituality has been subtly absorbed. Instead of being dangerous it has become cosy. ${ }^{40}$

My question is: where is the Goddess movement twenty years after this was written? There is no shortage of explanatory frameworks or hypotheses for the changes noted above: many map closely onto wellresearched transitions between second and third wave feminism, the deradicalization of certain social movements, the feminist backlash, the mainstreaming of the New Age, and the ever accelerating commodification of spiritualities. My favoured hypothesis is that the movement has become increasingly polarized along several of the aforementioned tensions, dividing along two trajectories: the esoteric/personal and the exoteric/ecological. The esoteric values Goddess as an inner reality, a extension of the self, an archetypal or mythic source of power, a spiritual lifestyle choice. The exoteric values Goddess as an ecological, pantheistic and/or cosmological whole, the living body of nature. But how to test this proposal? The most common methods involve gathering quantitative and qualitative social data - and these certainly have their place. An objectoriented approach, however, demands something rather different.

An initial object-oriented route forwards was the simple edict, 'follow the objects'. This stands in contrast with the well-worn 'follow the money' (economic analysis) or 'follow the signs' (interviews, discourse and textual analysis). Decentring the human in order to make sense of the assemblages/objects of Goddess traditions and practices seemed eminently reasonable here. Problems quickly surface, though, when attempting to demarcate these religions. Is one dealing with separate withdrawn religions/objects, for example: exoteric/ecological and esoteric/personal Goddess religions? Is one dealing with two religions/objects that constitute parts of a larger Goddess religion/object? Or is one only dealing with only one religion/object? As framed, these are ontological questions. What exists? Epistemological questions quickly follow, though, perhaps the foremost of which rest with the antirealist proposal that the answers given rest with the structuring power of the categories deployed. More practical ones pertain to matters such as how

40 Anon., 'Despair and Empowerment' in From the Flames 1 (1991), 4. 
does one analyse the relations the various objects enter into? How do those objects comprise and operate within larger religious assemblages and objects? How does one interpret the relevance of said objects for either the practitioners or the other objects? These questions are not to be ignored simply because object-oriented ontology places metaphysical analysis before that of epistemology. One simply proceeds with the conviction that there are real objects to be studied, and they are not enslaved to the human cogito and gaze. Humans are important, but they are not central.

With regard to my hypothesis that there are now two goddessoriented assemblages following their own trajectories, I share the following, provisional findings. Initially, it is clear that within the Goddess movement there are many religious objects which share common relationships, and move in similar orbits to one another, blocking any easy division into separate religious assemblages. For example, ceremonial, magical and ritual objects seem to be interchangeable across the movement. However, when one looks beyond these, and searches for other significant objects and relationships, the findings shift, moving toward the kind of categories and alliances of objects that I have proposed. On the one hand, there are aggregations of objects whose affects and causal powers cluster around an individual human practitioner and a set of fairly discrete concerns, emotional states and material conditions. Textual objects representative of these would be what may be called 'spiritual guides', such as 21st Century Goddess, Teen Goddess and A Goddess is a Girl's Best Friend. ${ }^{41}$ All of these attempt to draw one range of objects, such as crystals, oils, tarot decks, into a powerful alliance with others, such as those of beauty, business, love and wealth. The blurb for $21^{\text {st }}$ Century Goddess captures this particularly well:

Written by the Charlie's Angels of the New Age, this book will help you decide what to wear, how to choose the right man, decorate your

41 J. Adams, J. Glisic and A. Paul, 21st Century Goddess: The Modern Girl's Guide to the Universe, London: Corgi Adult 2004; L. S. Brockway, A Goddess is a Girl's Best Friend: A Divine Guide to Finding Love, Success and Happiness, New York: Perigee Books 2002; C. Wishart, Teen Goddess: How to Look, Love and Live Like a Goddess, Woodbury, MN: Llewellyn, 2003. See also, D. Gisonni, The Goddess of Happiness: A Down to Earth Guide for Heavenly Balance and Bliss, Makawao, HI: Inner Ocean Publishing 2005; F. De Grandis, Be a Teen Goddess!: Magical Charms, Spells and Wiccan Wisdom for the Wild Ride of Life, New York: Citadel Press, 2005; L. Simpson, Awaken Your Goddess: A Practical Guide to Discovering a Woman's Power, a Woman's Glory, London: Gaia Books Ltd 2001. 
bedroom, mix potions for love, happiness and success, make sense of your dreams, boost your luck and lower your stress levels, harness your psychic energy and show you how to throw a fabulous goddess party. Chapters include: Chakras and Auras; Magic and Rituals; Dreams; Crystals and Remedies; Astrology; Numerology; Psychic Power; Angels and Goddesses and Mind Miracles.

On the other hand, there is another 'goddess-oriented' assemblage which favours alliances with a very different set of material, political and social objects. Exemplary of this other assemblage of object relationships is Starhawk's summation of her commitments in Webs of Power: Notes from the Global Uprising:

A deepening earth-based spirituality led me into environmental and antinuclear activism, out of the sense that if the earth is sacred, we should prevent idiots from destroying her and us. Throughout the eighties and nineties I engaged in many nonviolent direct actions on the issues of nuclear power and weapons, and later on militarism, intervention in Central America, the clearcutting of redwood forests, AIDS, and other issues. I was part of a collective of nonviolence trainers and also helped to organize many of the actions. ${ }^{42}$

There may be some hesitation here on the part of the reader. Indeed, one ought to stop. It may be objected that I am selecting evidence, or objects, to fit my hypothesis. The counterclaim is that I am investigating what is real. I may be mistaken, but the attempt is to describe, analyse and make sense of what is there. Is there an assemblage of persons, spiritual self-help books, magical and ritual objects and lifestyle items that demands to be understood as one type of Goddess religion, while another, one that is more concerned with trees, nuclear power and alliances with political activists, ought to be accepted as another? I don't know. The best I can do is mobilize more evidence of objects and their association to support, or falsify, my case. The value of an object-oriented approach to the Goddess movement is not that humans are side-stepped or erased - they aren't but rather that sensitivity to a complex interplay of things, materialities and actants is required. Although economic, political, psychological and sociological avenues of enquiry may be opened up by such an approach, they are not imposed from the outset. One is asked to accept that religious movements and traditions, such as the Goddess movement, are constructed from diverse agencies, parts and formations of 'thing-power'.

42 Starhawk, Webs of Power: Notes from the Global Uprising, Gabriola Island, BC: New Society Publishers 2003, 4. 
Currently, there is simply nothing within religious studies that takes this proposal seriously and explores what dividends it might pay.

\section{What Matters?}

I conclude with a declaration. One ought to praise the labours and achievements of the gender-critical turn in the study of religions, and one ought to understand the genealogy of that critique. Much is owed to the legacy of Kant, and much is owed to the feminist struggle for a liberated world. Regrettably, the former increasingly constrains the aspirations of the latter. Antirealism is ill-suited to the liberation of the world. The time is crying out for a renewed thinking of the things-in-themselves and a revived metaphysical realism. This need not entail naive or immature realism; the errors of the past can be retained in memory. But it may need to be speculative. There can be no paradigm shift in the study of religion or gender until genuinely ontological questions are addressed. 